\title{
眼症状を伴う術後性副鼻腔囊胞の統計的観察
}

\author{
木村＼cjkstart仁・山口 秀樹・奥平 唯雄 \\ 高橋整・船坂宗太郎・飯塚 尚久* \\ 佐藤 恒正*
}

\section{Cystic Lesions of Paranasal Sinus with Eye Symptoms}

\author{
Hitoshi Kimura, Hideki Yamaguchi, Tadao Okudaira, \\ Osamu Takahashi and Sotaro Funasaka \\ (Tokyo Medical College) \\ Naohisa Iizuka and Tunemasa Sato \\ (Tokyo Metropolitan Police Hospital)
}

Thirty patients with post operative paranasal cysts and ophthalmological symptoms were treated at Tokyo Medical College Hospital from January, 1984 to December, 1987, 18 males and 12 females. They were classified into four groups according to the location of the cyst: 1) maxillary type, 14 cases, 2) maxillary-ethmoidal type, 6 cases, 3) ethmoidal type, 5 cases, 4) frontal-ethmoidal type, 5 cases. The average interval between the first sinus operation and the second operation for the cyst was 26.1 years. This was longer than the interval in patients with the usual form of postoperative cyst. briefly.

Exophthalmos was the most prominent eye disorder. The literature is reviewed

Key words: cystic lesion, post operative paranasal cyst, ophthalmological symptom

\section{はじめに}

副鼻腔囊胞は既往歴に副鼻腔手術や外傷があ るかないかにより，術後性，外傷性，原発性の 3 つに分類 性囊胞が最む普遍的なものである。副鼻腔は解 剖学的に眼窩内側壁，下壁と接しているため, 囊胞が大きくなると多彩な眼症状をきたす。ま た眼症状が初発のため患者はまず眼科を訪れ， その後，耳鼻科を紹介されて受診する症例も少 なくない，今回我々は，眼症状を有する術後性
副鼻腔囊胞30症例について, 年齢, 性差, 眼症 状の種類, 囊胞の分布範囲, 房数, 初回の副鼻 腔手術, 眼症状を呈した年数と眼症状の予後, 内容物などを検討した。 その結果, 従来の報告 と多少異なった結果を得たので文献的考察を加 え報告する。

\section{対象}

1984年 1 月より 1987 年12月までの 3 年間に複 視，眼球突出，流涙，視力低下などの眼症状を 訴えて, 東京医科大学, 東京警察病院, 新川橋 
病院を受診した患者30例で，いずれ屯既往に副 鼻腔手術を受けており，今回の手術により副鼻 腔囊胞と確定されたあのである。

\section{結果}

1. 年齢分布, 性差および患側

囊胞手術時年齢分布は図 1 に示したごとく, 30〜 80歳であり，40歳代が 9 人，50歳代が 10 人 と高頻度を示し, 平均年齢は49.5歳であった. 性別は男性18例，女性12例であった（図 1). 患 側については右側17例，左側12例で，なお，両 側性が 1 例あった。

2. 術後経過年数および病悩期間

前回の副鼻腔手術時より今回の眼症状を呈す るに至った期間は最低 9 年，最高 64 年であり， 大部分が術後 10 年から 40 年までの間にあり，中 であ術後20～29年が11例と最も多い頻度であっ た. また平均年数は 26.1 年であった（図 2 ).

3. 眼症状

眼症状は多彩で，一人で多くの症状を呈して いるため例数は70人多くなった（表 1 ). 表の如 く複視が15例と最屯多く, 次いで眼球突出11例,

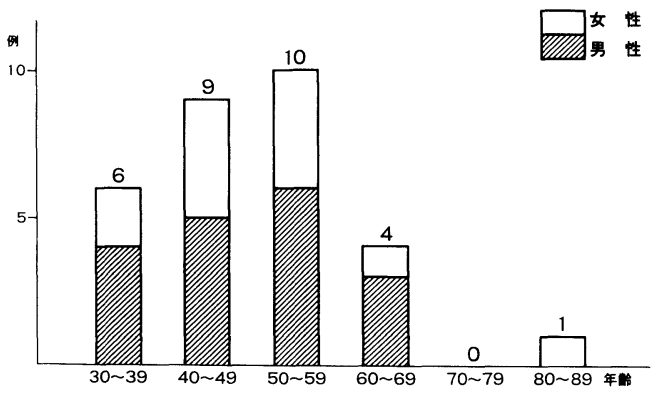

図 1 年齢分布之性差

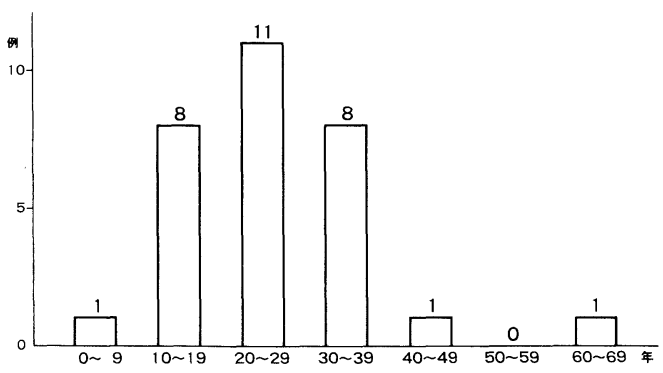

図 2 初回手術後経過年数
流涙10例, 視力低下 9 例, 眼痛 6 例の順であっ た．注意すべきは，視力低下 9 例中に霧視が 3 例あり，また視野障害 5 例中に 4 例が球後視神 経炎, 流涙10例中 2 例が涙囊炎を併発していた.

4. 囊胞存在部位之房数

術前の $\mathrm{X}$ 線診断（単純 $\mathrm{X}$ 線，断層撮影， $\mathrm{CT}$ ) と手術所見により判断した。囊胞の分布範囲 （表 2 ）は上顎洞にあるもの14例，節骨洞にあ るもの 5 例，上顎洞と節骨洞にまたがるむの 6 例，前頭洞に関係するもの 5 例であった。特に 上顎洞囊胞では広田 ${ }^{1)}$ の分類で言う上部中央型 と上部内側型が約 8 割を占めていた.

囊胞の房数は 1 房性18例 (60\%)， 2 房性 6 例 (20\%)，その他 6 例（20\%）であった。

\section{5. 囊胞部位と眼症状}

囊胞の部位と眼症状との関連を追求した（表 $3)$ ）上顎洞単独の場合は流涙，眼球突出，視力 低下が多くみられ，節骨洞または節骨十前頭洞 では複視が多い傾向がうかがわれた。 また症状 別に見ると，複視は節骨洞や前頭洞が関係して いる場合に起こりやすく，眼球突出は上顎洞や

表 1 眼症状の種類

\begin{tabular}{|c|c|}
\hline 視 & 15例 \\
\hline 眼 球 突 出 & 11 \\
\hline 流涙 & 10 \\
\hline 視 力 低下 & 9 \\
\hline 眼痛 & 6 \\
\hline 眼 瞼 腫 脹 & 5 \\
\hline 視 野 障 害 & 5 \\
\hline 眼球運動障害 & 5 \\
\hline 眼 圧 迫 感 & 2 \\
\hline 眼球結膜出血 & 1 \\
\hline 角膜知覚低下 & 1 \\
\hline
\end{tabular}

表 2 霊胞の存在部位

\begin{tabular}{lr|c} 
上 顎 & 洞 & 14例 \\
上顎洞十節骨洞 & 6 \\
節 骨 洞 & 5 \\
前頭洞十節骨洞 & 5
\end{tabular}


前頭洞，視力低下は上顎洞に病巣があるときに 起こりやすい.

眼球運動障害は上顎洞，前頭洞に多く，前頭 洞が関係すると上下方向の，節骨洞が関係する と左右方向の障害を起とす傾向がみられた。 た だし，症例数が上顎洞に多く，前頭洞のみの屯 のはなく，両者にまたがっている症例が多いた め，ここでは傾向を述べるに止めたい.

6. 初回の副鼻腔手術と今回の手術術式

初回術式は経上顎洞手術を含む上顎洞根本術 28例（93.3\%）と大部分を占め，鼻外前頭洞節 骨洞根本術は 2 例 $(0.7 \%$ ）であった（表 4). な扮鼻内節骨洞開放術症例はなかった。今回の 術式は鼻内法 3 例 (10.3\%), 経上顎洞法 20例 (68.9\%)，鼻外法 6 例（20.7\%）であった.

\section{7. 内容物の細菌検査}

結果が判明したもの16例のうち，陰性は13例 （81. 25\%）で陽性は僅か 3 例（18.75\%）であ った. その内訳は St. epidermidis 2 例, $\alpha$-st. hemolyticus 1 例であった.

8. 治療効果

複視と眼球突出は再手術後数日以内で著明に

表 4 初回副鼻腔術式

\begin{tabular}{|c|c|}
\hline 式 & 例 数 $(\%)$ \\
\hline 鼻 内篩骨洞開放術 & 0 \\
\hline 経上顎洞的副鼻腔手術 & $28(93.3)$ \\
\hline 鼻外前頭洞節骨洞根本手術 & $2(6.7)$ \\
\hline
\end{tabular}

改善され，部位による差はなかった。しかし視 力に関しては術後 1 力月以内に回復を認めたも のは 9 例中 3 例のみで，その内訳は著明改善 2 例 $(0.4 \rightarrow 1.2,0.2 \rightarrow 1.0)$ ，軽度改善 1 例（0.2 $\rightarrow 0.4 ）$ であった.

\section{考察}

眼症状を伴った術後性副鼻腔囊胞は，今回の 統計が示すように初回手術より10～40年の期間 において医師を訪れるのが特色であり，眼症状 の故に眼科医をまず訪れる例が少なくない，事 実，我々の30症例も13例（43\%）が眼科からの 紹介であった。

さて，発症時年齢は従来の報告2)3 ${ }^{23}$ にると 30〜 50歳代に多く, また性別では男性に多いが， この点は我々の結果と同様である．性別につい ては初回の手術総数の男女別検討がないと確か な事は言えないが，一般的には副鼻腔手術を受 ける率が20歳代前後の男性に多い。乙のため男 性の患者が多いのではないかと思われる．前回 の副鼻腔手術時より今回の眼症状出現までの期 間は最低 9 年，最高64年であり，前述のように 大部分が術後 10 年から 40 年までの間にあり，中 でも術後20～29年が11例と最も多い頻度を呈し ている. また平均年数 26.1 年 ${ }^{4)}$ であり，長い経 過期間をとるととが示された。つまり術後性囊 胞を放置しておくと，さらに数年から10数年前 後を経て眼症状を呈する可能性があると考えら れる。

表 3 囊胞部位と眼症状

\begin{tabular}{|c|c|c|c|c|c|c|c|}
\hline & & & 上 $_{(14 \text { 顎 }}$ 洞 & $\begin{array}{c}\text { 上顎洞 }+ \text { 篩骨洞 } \\
(6 \text { 例 })\end{array}$ & ${ }^{\text {篩 }}$ ( 5 骨 例) ${ }^{\text {洞 }}$ & $\begin{array}{c}\text { 前頭洞＋節骨洞 } \\
(5 \text { 例 })\end{array}$ & 計 \\
\hline 複 & & 視 & $4(14 \%)$ & $3(21 \%)$ & $3(23 \%)$ & $5(45 \%)$ & 15 \\
\hline 眼 & 球 突 & 出 & $5(18 \%)$ & $2(14 \%)$ & $1(7 \%)$ & $3(27 \%)$ & 11 \\
\hline 流 & & 涙 & $6(21 \%)$ & $2(14 \%)$ & $2(15 \%)$ & 0 & 10 \\
\hline 視 & 力 低 & 下 & $5(18 \%)$ & $2(14 \%)$ & $1(7 \%)$ & $1(9 \%)$ & 9 \\
\hline 眼 & & 痛 & $2(7 \%)$ & $3(21 \%)$ & $1(7 \%)$ & 0 & 6 \\
\hline 眼 & 瞼 腫 & 脹 & $2(7 \%)$ & $1(7 \%)$ & $2(15 \%)$ & 0 & 5 \\
\hline & 野 障 & 害 & $2(7 \%)$ & $1(7 \%)$ & $2(15 \%)$ & 0 & 5 \\
\hline 眼王 & 球運動站 & 害 & $2(7 \%)$ & 0 & $1(7 \%)$ & $2(18 \%)$ & 5 \\
\hline
\end{tabular}


眼症状の種類に関しては他の報告5) 6) によれ ば眼球突出が最も多く, 次いで視力障害が多い と述べているが，我々の場合は，複視が15例と 最も多く, 次いで眼球突出の11例，流涙，視力 低下の順であった。

囊胞部位と眼症状の関係では，前頭洞霊胞の 場合では，眼球突出，眼球偏位，眼瞼腫脹，複 視等の多彩な眼合併症6) 9 をきたしやすいと いう指摘がある。また後部節骨洞などの後部副 鼻腔病巣では視力障害, 眼球運動障害 ${ }^{102}$ 12) が 起きやすいと言われている，我々の集計では全 体的にはほぼ同様の結果が得られた。注意すべ きは眼球突出は前頭洞のみならず上䪽洞の症例 に，また視力低下は篩骨洞のみでなく上顎洞の 場合にも見られたととである.いうまでもなく， 前頭洞, 節骨洞に発生する彨胞は眼窩との位置 的関係により複視, 眼球突出などの眼症状が起 きやすいのは当然であるが，上顎洞震胞でも時 として多彩な眼症状を呈するととに留意する必 要がある。副鼻腔霊胞による眼症状で最も問題 になるのが視力低下であろう。視力低下には視 野障害を伴う視神経障害や眼痛を伴う orbital apex syndrome ${ }^{13) 14)}$ などがある. 我々も視力低 下を認めた 9 例について検討を加えた。 上顎洞 単独で視力低下をきたした 5 例のうち 3 例は数 度の手術を受け，他と比較して手術より発症ま での期間が長期であり，上顎洞下壁の骨欠損を 含み，数力所の欠損部があった。 そのため眼 球本体の圧迫により二次的に眼圧六進が進行 $し^{15)}$ ，霧視や虹視様の症状にて視力低下を訴え るむのと，虚血性視神経によるもの，また襄胞 の圧迫により二次的に副鼻腔炎の病变が周囲の 眼窩, 視神経管, 交文部付近に炎症が波及して いくのではないかと推察される。また穊骨洞囊 胞の場合は囊胞が眼球を圧迫し，二次的に視神 経を圧迫障害するためや震胞加らの炎症波及の ためではないかと考えられた。

眼症状を伴う霝胞の診断には, 従来の単純 X 線, 断層撮影などの検查の他に CT $\operatorname{scan}^{16)}$ に よる局在部位ないしは進展範囲を確かめること
が大切である (図 3). 事実, 視力障害をきたし た群の全例に括いて，CT 像上で眼窩内へ霣胞 の進展範囲, 骨欠損の部位が明瞭に認められて おり，CT の有用性が確認された。

治療法は抗生物質やステロイドの内服と犬歯 窩よりの穿刺などにより，一時的に症状が改善 する症例もあるが，手術が第一選択である。手 術法は震胞の部位の大きさ，数によって異なる. 上頡洞囊胞の場合には一般に比較的大きく眼窩 壁が破壞され，賈胞の一部が眼球を支持してい る場合が多いため襄胞剝離に拘わる必要はな い. むしろ，自然口の開大や下鼻道排泄孔を広 く形成するのみで充分なととが多い、篩骨洞鼠 胞の場合は，囊胞の完全摘出17)ないしは鼻内 法による開放術 ${ }^{18)}$ が一般的である. 今回の症例 のうち前部節骨洞で前頭洞にかかっている症例 には鼻外法を，後部節骨洞の症例には鼻内法を 行った. 前頭洞囊胞では鼻内法と鼻外法を併用 し，鼻前頭管の長期にわたる十分な開大と肉芽 再発防止に努めた. 即ちシリコンのドレーンチ ユーブを 10 日間前後留置したが，今後留置期間 を延長し治瘠例の比較検討を加えたい.

さて, 術後性霊胞の場合, 貯留液が無菌的屯 しくは粘液性の mucocele ${ }^{199}$ が多い之言われて

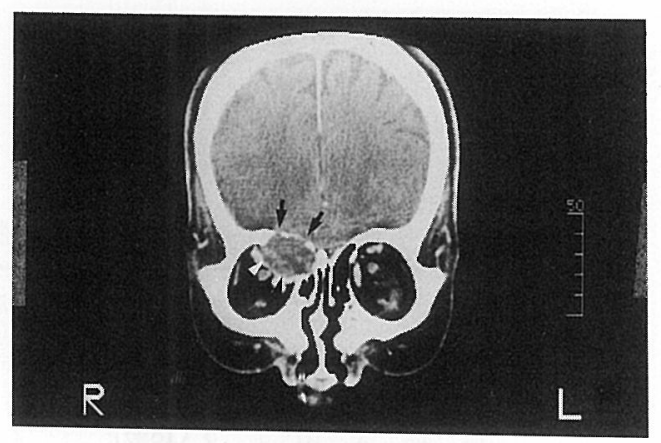

図 3 56歳, 女性の CT 像

右前頭洞から後部節骨洞にかけての䨞胞の症状とし て眼球突出と複視を呈した.

CT 像 : 眼窩天蓋部で骨は薄〉破壊し, 糞胞壁被膜 の high density と内容の low density を認める（矢

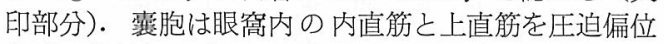
させ，視神経と接している。 
いる. 今回も細菌検査を施行したが，結果は判 明した16例中13例が陰性であった。乙のことか ら pyocele を起こして細菌が直接視神経に波及 して，視神経炎を起こす20)というよりは囊胞内 に分泌液が貯まり，リンフォカイン21) などに より骨融解が進み囊胞が眼窩内に拡大したため の二次的な圧迫が第一原因であると考えるのが 妥当であろう. 従って, 眼症状が併発した場合 は早急な手術を必要とする.

最後に，治療の効果について言及する。まず 複視に関しては，手術直後から遅くとも数日以 内に改善が見られ，約87\%に回復がみられた。

しかし，視力に関しては回復がみられたのは10 例中僅か 3 名であった。他の報告(411)でも似た ような結果となっている，原則的に言えば，視 神経が圧迫による不可逆的障害を受ける以前に 治療，手術を行えば，元の状態に回復する屯の と考えられるが，どの様な視力低下の場合，再 手術で視力回復に導けるかは不明であった。し かしながら現実には，副鼻腔手術を受けた患者 は, 囊胞が大きくなり顔面腫脹, 疼痛, そして 眼球突出が発来して初めて耳鼻咽喉科を受診す ることが多い，このため視力に関する啓蒙をさ らに進める必要があると考えられる。

\section{まとめ}

1. 眼症状を呈して手術治療を行った術後性 副鼻腔囊胞 30 症状について検討した.

2. 眼症状を呈する症例は40～50歳代に多か った.

3. 発現期間は術後20～29年を呈した症例が 多かった。

4. 眼症状のうち複視が最も多く，次いで眼 球突出, 流涙, 視力低下の順であった.

5. 複視は篩骨洞や前頭洞が関係している場 合に多く, 眼球突出は上顎洞, 前頭洞に, また 視力低下は上顎洞に多い傾向にあった.

6. 初回手術では上顎洞根本手術を受けた症 例に多く発来し, 中鼻道よりの交通路保存が肝 要と考えられる.
本論文の要旨は第50回耳鼻咽喉科臨床学会総会にて 口演した。

\section{参考文献}

1）広田佳治, 飯沼寿孝, 渡辺 勲, 他 : 多胞性術後 性上顎囊胞の臨床的研究. 日耳鼻 $85: 756 \sim 765$, 1982.

2) 原田 保, 石田 稔：術後性のう胞腫症の臨床的 検討. 耳鼻臨床 73増 $1 ： 395 \sim 398,1980$.

3）梅崎俊郎, 松尾浩一, 和田 繁, 他 : 当教室にお ける術後性上㴿囊胞の臨床統計的観察. 耳鼻 31 : 346 351, 1985.

4) 石田 稔, 堀 哲二, 玉置弘光, 他 : 眼症状を伴 った副鼻腔疾患の臨床観察一過去10年間の観察一. 日耳鼻 $85 ：$ 904 911， 1982.

5 ）森本賢治, 榎本和子, 小林一豊, 他 : 眼窩合併症 を伴った副鼻腔囊胞. 耳鼻 $31: 466 〜 470 ， 1985$.

6 ）白岩恒男：眼症状を伴った副鼻腔囊腫の検討一特 に蝶形洞囊腫の手術法を中心として一. 日耳鼻 $48: 375 \sim 380,1976$.

7 ）市野幸則, 宮村健一郎, 田中憲雄, 他 : 失明を来 たした副鼻腔ムコツェーレの 3 症例.耳鼻臨床 $74: 1409 \sim 1415,1981$.

8) 中山堯之, 本庄 䈆, 島野圭司, 他: 激烈な眼症 状を呈した前頭洞, 節骨蜂巣 pyocele の 1 例. 耳 鼻臨床 $69: 237 \sim 240,1976$.

9 ）広田佳治, 清水弥生, 大澤博之, 他: 前頭洞囊胞 の臨床的研究. 日耳鼻 $89: 731 \sim 743,1986$.

10）藤田洋右, 北村 武, 戸川 清, 他: 視覚異常を 伴った後部副鼻腔炎について。 日耳鼻 $74: 1449$ $\sim 1454,1971$.

11）藤谷哲造, 志水雄輔, 井之口順, 他 : 蝶形洞囊腫. 耳鼻臨床 $68: 1127 \sim 1132 ， 1975$.

12）小田 恂, 野村恭也 : 眼窝尖端部症候群を呈した 蝶形骨洞ムコッェーレの1例. 耳喉 $43: 569 \sim$ 574, 1971.

13) Smith AT : Orbital apex syndrome. Otolaryng $67: 742,1958$.

14）堤 冒己：複視を主訴とした慢性副鼻腔炎に就て (orbital apex syndrome 之副鼻腔炎). 耳展 3: 73〜77, 1960.

15）仁田正雄: 眼科学. 582頁, 文光堂, 東京, 1973.

16）平木真滋雄 : 視力障害を合併した篩骨洞囊胞の 2 例. 耳展 $55: 307 \sim 309$, 1983. 
17）小池祐一：耳鼻咽喉科領域における眼球突出一副 鼻腔囊腫症例を中心に一. 耳鼻 $19: 365 \sim 373$, 1973.

18）藤谷哲造：蝶形洞亭腫一診断と治療一. 耳鼻臨床 $68: 1127 \sim 1132,1975$.

19）深道義尚：眼症状を呈したムコッェーレ・ピオッ エーレの 6 例. 眼臨 $63: 287 \sim 293,1968$.

20）飯沼寿孝：失明を合併した前頭洞ピオツェーレ. 耳喉 $43:$ 309 313, 1971.
21) Evance C : Aetiology and treatment of frontoethmoidal mucocele. Laryngol Otol $95: 361 \sim$ 375, 1981.

$\left(\begin{array}{l}\text { 原稿採択 : 平成元年 } 4 \text { 月 } 20 \text { 日 } \\ \text { 別刷請求先 : 木村 仁 } \\ \text { 干160 東京都新宿区西新宿6-7-1 } \\ \text { 東京医科大学耳鼻咽喉科学教室 }\end{array}\right)$ 